\title{
Recent Residential Mobility in Spain
}

\section{Manuel García Docampo}

Universidade da Coruña; Docampo@udc.es

\section{Doi:10.5901/mjss.2016.v7n3s1p192}

\begin{abstract}
This paper presents some of the main conclusions which can be drawn from internal migration in Spain. We have a double objective: on the one hand, to present the volume of flows and, on the other, to interpret observed patterns within them. The data originates mainly from the Residential Variations Statistics (official Spanish register of residential changes). The hypotheses are classified with a criterion for completeness: considering all possible alternatives. The findings show that the urban-centripetal flow ceased to be significant in the 1980s. Although in the first decade of the 21st century, all habitats grew, thanks to foreign immigration, cities registered negative migratory balances. By contrast, for the first time, rural areas recorded a positive demographic balance. The counterurban theories are called into question in light of recent data and of the classification used.
\end{abstract}

Keywords: Territorial dynamics, Demographic dynamics, Reurbanization, Urban deconcentration, Counterurbanization

\section{Introduction: The Study of Demographic Dynamics}

Until well after the middle of the twentieth century, there was a broad and latent consensus on territorial dynamics. The hegemonic theory held that all societies walked unerringly towards a situation in which the majority of the population would reside in cities. If this were to happen, a rural society, which defined pre-industrial societies, would become another urban society. In this context, present-day rural life would be relegated to a marginal and regressive status.

Nevertheless, as of the 1970s, first in America and then in many other European countries, evidence that growth in "non-metropolitan" areas was higher than that of the "metropolitan"1 areas became noticeable. With Beale and Berry, in North America, and Vinning and Kontuly in Europe, to name just a few pioneering examples, a new paradigm began to emerge, as opposed to the previous orthodox one, often referred to as "counterurban". According to the latter, as originally formulated, a veritable "Clean " had taken place in the history of mankind, opening up a new cycle of territorial dynamics in which individual preferences for more natural habitats, of lower volume and density, would become increasingly prevalent. The new cycle is also known as "rural turnaround".

However, the recorded history of the theory and empirical data registered rapid and drastic reversals (García Docampo, 2014). While in the USA, the 1980s reflected higher growth in urban areas (12\% versus the $2 \%$ of nonmetropolitan); many European countries were registering counterurban processes. The diversity became more apparent in the 1990s: in the USA a true counterurban revival was noticeable (Beale et al., 1990; Long et al., 1997.); in Europe, the diversity observed merely brought about huge scholarly confusion. Thus, countries that previously recorded an urban crisis changed and again to show clear evidence of concentration, such as Austria, Sweden (Champion, 1992), Belgium, Germany (Frey, 1995); however, many also showed signs of deconcentration: Canada (Dahms et al., 1999), Denmark, France, Ireland, and Italy (Champion, 1992)2.

With the new millennium, evidence of redevelopment becomes more visible, both in Europe (Bromley et al, 2007;

\footnotetext{
1 The contested use of US Metropolitan categories versus Nonmetropolitan areas has generated much controversy in the analysis of current trends. An analogy has on occasions been derived from these and their balances with rural and urban spaces. However, this analogy presents three types of problems: 1) non-metropolitan areas include both urban (including cities) and rural areas; 2) a county that is considered "metropolitan" in a census will not necessarily be considered as such in the next one, as modifications due to the expansion of an existing metropolitan may take place, or a new metropolitan area could be generated from the growth of a "nonmetropolitan" area; 3) In the nonmetropolitan categories there are counties adjacent to metropolitan areas which could be locating a major part of non-metropolitan growth.

2 Presently, different interpretations coexist. On the one hand, the hopes of the counterurbans, who envision a return to the path of the 1970s, that was broken during the past decade, but interpreting that regression to be in its final throes before the cities enter into their ultimate and fatal crisis. On the other hand, the counter-urban interpretation continues to be challenged, insisting that what grows are mainly, and in the majority of cases, the rings and city suburbs.
} 
Cheshire and Gordon, 2006; Turok and Mykhnenko, 2007) as in America (Johnson, 2006) and in other continents (Priemus 2003 and Buzar et al., 2007). The paradigm is strong and dominant (Haase et al., 2010) but does not override the pro-rural thesis. The adjustment to the theoretical model of cyclic ${ }^{3}$ sequence of Van den Berg et al. (1982) seems quite acceptable (Parr, 2012); although, from certain positions, the emphasis is now more clearly on the simultaneity and disorder of the sequential processes (Couch et al., 2005; 2002; Turok, 2007) and even on a tendency towards the stabilization of all habitats (Haase et al., 2010). However, empirical evidence of rural revitalization allows them to continue sustaining the counterurban hypotheses (Halfacree, 2012, Farrell, 2012).

In the case of Spain, the rural exodus to the cities was particularly strong between 1950 and 1980 (Figure 3). However, as Camarero (1993) points out, the net migration of rural municipalities since the mid 1980s tends to zero, balancing inputs with outputs, and therefore verifying the hypothesized equilibrium of Wardwell (1977). In the 1990s, the Spanish rural municipalities (population under 10,000) were already growing (García Sanz, 1997), a trend which is more evident in the new millennium. Notwithstanding, cities also recovered their prominence (Nel.lo, 2004, Pozo Rivera et al., 2009), intensifying the hypotheses based on the processes of reurbanization. García Docampo et al., (2012), presents not only the evolution of rural and urban areas throughout the twentieth century, but also an interpretation, contrasted empirically for the case of Spain, of how this evolution corresponds to a model determined by "Territorial Transition". This postulates that deconcentration is only one phase in a process that concludes in a new territorial rebalancing, where both rural areas and urban areas and their outskirts grow significantly over the first decade of the 21st century.

Contributions to the study of internal migration in Spain were much more abundant, as can be seen, for example, in the bibliographic review by Silvestre (2002), but especially from a more local and sectoral analysis perspective. Rodríguez et al. (2004) provides evidence of the contribution made by "retirement migration" to the renewal of the rural population, and Oliva (2010) extends the significance to other groups of foreign immigrants. Lamela (2006) shows how foreign immigrants are also the ones that move the most internally. The treatment of the impact between changes of residence and other social variables has also generated an extensive amount of literature, as in the case of rural gentrification (Janoschka et al., 2014; Duque Calvache, (2014), gender (Gurrutxaga, 2013), age (Hierro, 2006) or changes in the "perception" of rurality (Rivera, 2013). Catalonia is one of the Spanish regions that has most carried out exhaustive research on migration (Solana, 2010, Bayona et al., 2013, Pallares et al., 2014), although other regions have also received attention, such as Pozo Rivera et al., (2009) on Madrid, and Morillo et al. (2010), on Andalusia.

Both in Spain and internationally, the said academic literature has sought to find evidence of what the recent pattern is and, by extension, what will be the future trend of territorial dynamics and, in particular, of rural areas.

\section{Methods and Data}

\subsection{Hypotheses}

Hypotheses are presented in a thorough manner, considering each and every one of the possible alternatives of territorial dynamics. The comparison is made with data referring to Spain, but the theoretical context goes beyond the national context in order to understand the trends observed in Europe and other countries that are fundamental to the OECD.

To understand what is happening in a given society at a spatial level it is necessary to have knowledge of which are the relevant territorial categories. The urban-rural dichotomy is a classic debate among them, and it is not exempt of controversy. It is important to maintain these categories because they summarize a broad process of social change in a paradigm that is academically well understood; the historical development of rural societies led to an inexorable urbanization process and the concentration of population in cities. However, simplifying this duality hinders the understanding of some of the processes that have taken place since the last third of the 20th century. At the very least, it is essential to include a new category, which we could call "periphery" (ring), like a crown inserted into the ancient rural areas surrounding the major cities. Even though subsequently, to empirically interpret the contemporary Spanish reality, we have introduced some much finer clarifications; the fundamental triad consists of "cities", "rings", and "rural areas". These three areas are far from being internally homogeneous and relationally different, but instead, the heterogeneity existing in each of them and the unclear barriers that identify them turn them into weak concepts because of definition and delimitation problems. Still, they are the interpretative protagonists of territorial dynamics. To exclude any of them

\footnotetext{
${ }^{3}$ The cyclic sequence began with the "concentration" of population in the cities, followed by successive phases of suburbanization (followed), with the simultaneous growth of cities and their fringes, and deconcentration (or de-urbanization), with the growth of fringes and other rural spaces, during periods when cities did not grow.. Finally the process culminated in a fourth phase of reurbanization, where the main cities recovered the hegemony of their dynamism and growth (Van den Berg et al., 1982).
} 
would impede the understanding the past, the present, and the future evolution of the system of population settlements.

In fact, all the evidence that Beale, Berry and his other contemporaries presented on non-metropolitan growth in the 1970s in the USA was soon questioned, on the suspicion that they did not adequately measure the rural areas or even "non metropolization" itself. The main reason was based on the premise that growth was focused more on periurban areas, which practically formed part of the suburban fringe areas. Early on Fuguitt et al. (1975), Vining and Strauss (1977) and Gordon (1979) perceived how contiguity with urban areas is relevant to understanding the location of the growth of small settlements. Criticism of this ruralist generalization of all non-metropolitan areas became more evident in the 1980s (Hall et al., 1980) considerably damaging the credibility of the counterurban paradigm. Since the 1990s, some very decisive analyses (Long et al., 1997; Johnson et al., 2005: Wang, 2006) began to show that a clear conclusion can be drawn. In the case of North America, most population growth in the second half of the 20th century focuses on "new metropolitan" counties; in other words, counties that went from being non-metropolitan in the 1970s to being metropolitan in a later census ${ }^{4}$. The reason for the change lies in the peripheral location of the counties and in that they are adjacent to metropolitan areas.

In the simpler and also more useful version of territorial dynamics, from a theoretical point of view, there are three relevant spaces for the analysis of internal migration (Van den Berg et al, 1982; Elliot, 1996; Parr, 2012): the traditional compact city (core), the suburban peripheries (fringe) and the rest dominated by rural areas (rural). Despite the huge reduction that this represents, giving priority to criteria of parsimony, this triad makes it possible to efficiently understand (better than other more complex taxonomies) alternative theoretical hypotheses. Leaving out the evident internal diversity of each habitat, one can easily see the semantic relation that characterizes them. Each, in turn, may increase or decrease, regardless of the behaviour of the others, which makes it possible to develop a limited number of combinations (presented in Figure 1), each of which responds to a different kind of dynamic. The possible hypotheses originate from the combination of the dynamics of each of these three habitats. By carrying out a simplified differentiation of the spaces, dividing them into three groups (Traditional Compact Cities, Periphery and Rural) and identifying in each of them only two possible dynamics (growth or crisis, symbolized respectively with the sign + or - I =), 8 alternative hypotheses ${ }^{5}$ are produced (García Docampo, 2014).

Dominant patterns can be observed during each historical moment and they are characteristic of some of the alternative situations. Thus, in a feudal society a pre-industrial "equilibrium" was recorded, with growth both in cities and rural areas (the periphery did not yet exist as a territorial entity). In this first phase, the growth rates in the different territorial habitats are quite similar (De Vries, 1995). The course of history is accompanied by industrialization processes, first with a high concentration of population in cities and a massive rural exodus (concentration), and then with the opening up of a phase of centrifugal expansion in cities in which core and fringe grow simultaneously (suburbanization). More recently, the core dynamics have become stagnant (or decrease) and those of the fringe have been even further activated (decentralization). A particular case of the latter is produced when it is the rural areas that are revitalized (counterurban). Finally we have the current situation. The questions referring to the present and the future are still open, summarized in the following alternative hypotheses: either an urban revival takes place (redevelopment), or only (or principally) rural areas grow (counterurbanization) or preferably the peripheries of major cities (deconcentration), or the peripheral areas grow as much as the rural areas (de-urbanization), or lastly one of the situations contrary to generalized growth or decline takes place.

\footnotetext{
${ }^{4}$ The joint work of Johnson, Nucci and Long (Johnson et al., 2005) is particularly telling. They divide the counties of the U. S. into four groups. Firstly, the nonmetropolitan, which remains in that category both in the 1963 census as in the one for 1993. Secondly, those who switch to the metropolitan category, known as "New Metro". In turn, the metropolitan is divided into two groups, resulting in a third category of counties already densely populated in 1963, the "Core Metro", and finally, one last category reserved for the metropolises not very densely populated in 1963 (the "noncore"). Two main conclusions can be drawn from their study: 1st) Growth in the 1970s basically took place in counties that in subsequent censuses were considered as metropolitan ("New Metro"); 2nd) The Rural rebound of the 1990s however, can in fact be confirmed with the empirical data presented, reflected in the growth of non metropolitan counties that exceeds not only the core, but also the noncore. It is also true that this cycle began in the late 1980s and clearly ended in the second half of the 1990s..

${ }^{5}$ Actually, transfers with the repetition of 2 elements (growth or stagnation, symbolised in Figure 1 with + and $=/-$ ) taken for each habitat (which are three: Core, Ring, and Rural). Where $n$ stands for the number of elements and $r$ for the cases studied, the calculation of possibilities is $n r=23=8$.
} 


\subsection{Classification of Spanish Municipalities}

The empirical comparison that could answer the above questions in the case of Spain requires a process of territorial breakdown that in this instance has been resolved by using the municipalities (NUTS IV) as a reference. Clearly, this presents some problems, namely that a municipality can contain both rural and urban spaces. However, there are more advantages than disadvantages, compared to other alternatives (such as the Singular Population Entities of the INE (Spain's National Statistic Institute)). The advantages include: the amount of sociodemographic information available, the accuracy of the physical demarcation to geolocate the data, and the municipal hyperfragmentation of Spain's territorial structure (more than 8,000 municipalities), which keeps the effects of internal heterogeneity to a minimum.

In a second phase, when shifting from the theoretical model to the applied one, further to the above, we added a new type of habitat to the three former ones. The reason for this new inclusion is due to empirical difficulties in clearly separating Urban from Rural in some cases. This led us to consider an intermediate habitat, referred to herein as Urban Minor. It includes spaces (municipalities) that are medium-low in size, that are far removed from the concept of rurality, but with a weak degree of "city". They are municipalities with more than 10,000 and less than 35,000 inhabitants, not included in the categories of "city" or "Periphery".

A consideration of four types of habitats was thus established; cities, suburbs, small urban and other municipalities. We used the Atlas of Housing (Department of Housing, 2007) as a general basis for the classification of Spanish municipalities. We performed a number of changes: $1^{\text {st }}$ We used strict criteria to redefine "city" municipalities (Figure 1) following a logic of "historical volume"; $2^{\text {nd }}$ - We associated them with the municipalities which the Housing Atlas 2007 considered to conform to its Urban Area, which we call "peripheries"; $3^{\text {rd }}$ - We considered the rest of the municipalities which the Atlas classifies as Small Urban Area, not peripheral to a city, such as Minor Urban, and included in that category all municipalities not considered "Periphery" (Ring) with more than 10,000 inhabitants in 2011; $4^{\text {th }}$. The rest of the municipalities are included under "Rural". The positioning of each municipality in one category or another was done through a process of automatic classification, based on the fulfilment of the criteria for inclusion and their system of prevalence. These criteria are shown in Figure 1. During a later stage, the rural habitat was broken down into three different groups: Rural Manualized, Rural Agricultural, and Rural Inactive.

\begin{tabular}{|c|c|}
\hline HABITAT & CRITERIA FOR INCLUSION \\
\hline Cities & $\begin{array}{l}\text { Any municipality that meets the following criteria simultaneously is considered a city. } \\
-\quad \text { Had a total population of } 15,000 \text { or more inhabitants in } 1910 . \\
\text { - } \quad \text { Had a total population of } 30,000 \text { or more inhabitants in } 1930 . \\
\text { - } \quad \text { Had a total population of } 30,000 \text { or more inhabitants in } 1981 . \\
\text { - Had a total population of } 35,000 \text { or more inhabitants in } 2001 . \\
\text { Similarly, all municipalities that are provincial capitals even if they do not comply with the above criteria are considered } \\
\text { cities. }\end{array}$ \\
\hline Periphery & $\begin{array}{l}\text { Municipalities that appear as part of a Great Urban Area in the Atlas of Housing (2007) are considered "peripheral" (not } \\
\text { included in cities). In this case the large urban areas are characterized by having at least a municipality of 50,000 or more } \\
\text { inhabitants and other municipalities included in large urban areas must have } 1000 \text { or more inhabitants }\end{array}$ \\
\hline Urban Minor & $\begin{array}{l}\text { The Urban Minor, or also called Small Urban, are classified according to three criteria: } \\
\text { 1. Not listed under the category of Cities or Outskirts } \\
\text { 2. Having } 10,000 \text { or more inhabitants in } 2011 \\
\text { 3- Appear classified as Small Urban Area Municipalities in the Atlas of Housing } 2006\end{array}$ \\
\hline Rural & $\begin{array}{l}\text { Other municipalities not included in any of the above categories are further divided into three subgroups: Rural } \\
\text { Manualized, Rural Agricultural, and Rural Inactive. Criteria for classification in each of the rural municipalities in one of } \\
\text { these subgroups depend on their social and occupational structure. A system of automatic classification, based on profiles } \\
\text { was used. }\end{array}$ \\
\hline
\end{tabular}

Figure 1. Criteria for the classification of Spanish municipalities by habitat

Source: Developed by the author

\subsection{Data}

The source for all the data is the "Instituto Nacional de Estadística" (National Statistic Institute ("INE")); the official statistic agency of the government of Spain). Mainly, we used two operations: the Residential Variation Statistics, "EVR" [Estadística de Variaciones Residenciales], which is an on-going administrative record that collects the changes of address of the population, and as reference for the overall population at all times, we used the Census and Municipal Population Registers (exhaustive collection and cross socio-demographic data). Information was also provided by other 
auxiliary sources such as the Natural Population Movement, "MNP" [Movimiento Natural de la Población], which reports on births and deaths, and the Migration Survey, "EM" [Encuesta de Migraciones] with data obtained from surveys focused on a representative portion of the migrant population complemented partial aspects of our main objective.

\section{Discussion}

\subsection{Evolution of Habitats in Spain}

During the first half of the 20th century, the process of concentration of population in Spanish cities was progressive. During the middle of that century a pattern of change is perceived, resulting from the strong impact of suburbanization processes, while the rural exodus also becomes more intense, reaching its peak in the early 1970s (Precedo Ledo et al., 1985 ). In the 1980s, the trend drifts slowly but steadily towards a rebalancing of growth, that is less intense, but reaches every single habitat as of the beginning of the new millennium (García Docampo et al., 2012).

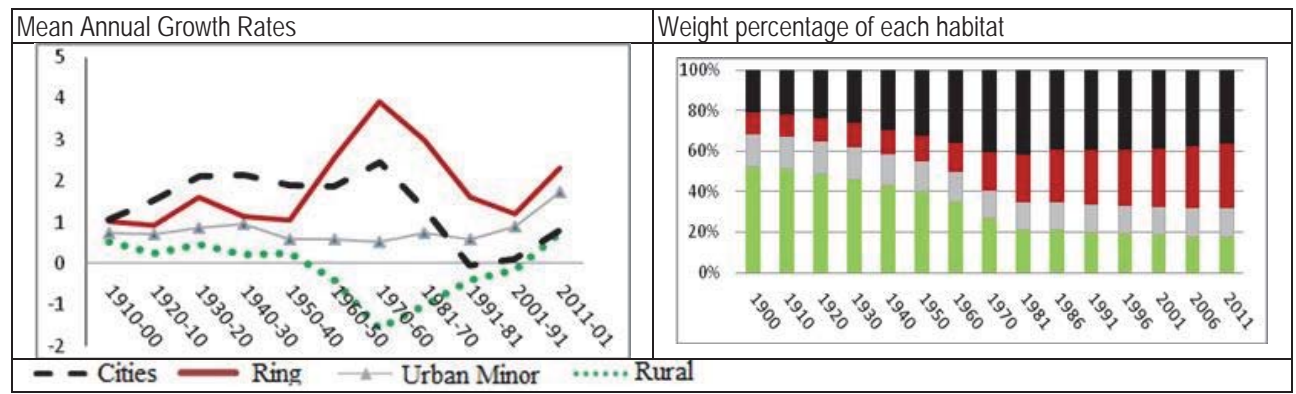

Figure 2. Evolution of each Habitat in Spain

Source: Census of Population (for years ending in 0 or 1) and Municipal Register for years ending in 6 (INE).

In retrospect, Spain went from being a country with over $55 \%$ of its population living in rural municipalities, in the early 20th century, to becoming a more urban society. The rural habitat was relegated to just below $20 \%$ of the population at the beginning of the 21st century (Figure 3). The migratory component is the explanatory cause for the variation in inhabitants. After the historical rural exodus, in the recent period which began in the 1980s, the patterns appear semistable. It is a known fact that fertility dropped sharply between the mid 1970s to the late 1990s (Goldstein et al., 2009). The drop took place in a similar way in all the habitats, although the Crude Birth Rate (CBR), included herein (Figure 4), hides the differences in the age pyramids for each one. It does, however, provide a better measurement of the intensity of natural increase per thousand. In absolute terms, only Rural records a negative balance as of the mid 1980s, and until the present day it maintains a very slow downward trend in values that, all in all, account for a loss of 20 inhabitants per year. The remaining habitats gained population by natural increase. The suburbs broke the historical hegemony that cities had held until the 1980s. Attracting young inhabitants resulted in the favourable balances that, as a whole, represent annual net gains of nearly 80,000 inhabitants since the beginning of the new century. Cities, in turn, registered a rapid drop in their balances that went from a net gain of more than 200,000 inhabitants annually in the early 1970 s, to recording negative values in the late 1990s. Nevertheless, with the new millennium, they returned to positive values, with total gains of around 30,000 inhabitants (Pozo Rivera et al., 2009). Finally, the behaviour of the municipalities that we include under the category of Urban Minor is very similar to Rural, but the values are always better for the first than for the latter. 


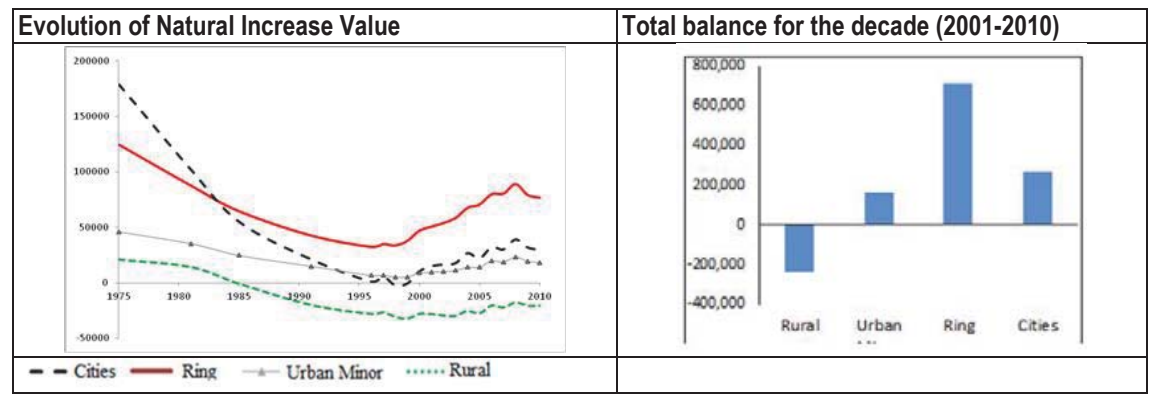

Figure 3. Natural Increase by habitat in Spain

Source: Natural Population Movement (Microdata, INE) and the Residential Variation Statistics (Microdata, INE).

As mentioned earlier, the degree of migration is the main cause for growth and decrease in each habitat. In the mid 1990s the rural habitat as a whole yielded a positive migration balance. Only cities (and very occasionally at that) registered negative values.

Although it has greatly improved, the Residential Variation Statistics ("EVR") collects data for only part of the internal migrations. This has led us to question its validity on several occasions. The method based on the difference between Stock and Natural Increase permits us to estimate variations that are more intense, but that essentially do not modify the patterns registered in the records. The higher deviations occur in the outskirts and rural areas. Although they do not follow a set pattern, the deviations tend to be lower as of the year $2002^{6}$.

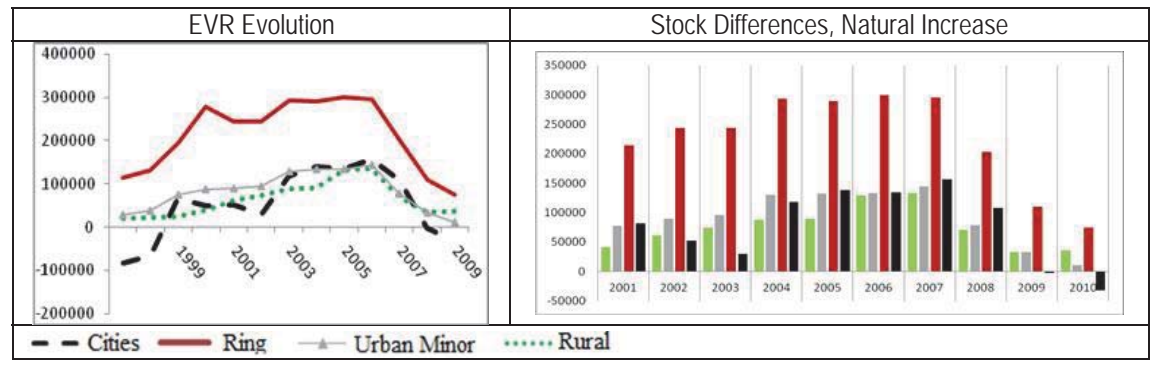

Figure 4. Internal Migration in Spain

Source: Microdata from the Residential Variation Statistics (National Statistic Institute of Spain).

The growth of each habitat is primarily the result of its migratory behaviour, although, as shown in Figure 4, only the rural areas have a negative natural increase value. The migration balance is positive in all habitats, including Rural (Figure 5). But in this case, the logic of suburbanization and urban deconcentration is at the root of the explanation of what took place over the last decade. Even interpreting the general drop in the contribution from migrations as of the economic recession of 2007, these logics are still valid or, if possible, more evident.

The significant volume of net migration concentrated in the peripheries conceals the relative weights of each habitat in terms of its population size. However, adjusted by population, the only habitat showing surplus values are the peripheries of Urban Areas. In 2010, for each inhabitant residing there, another had arrived (actually 1.03) over the past decade (Figure 5). Cities, however, show a weaker attraction (Odds ratio $=0.72$ ). The Rural areas, although with a negative balance, scale down this reduction to 0.85 (that is to say, the replacement is not covered, and for each inhabitant in 2010, 0.85 of a person arrived, instead of a whole).

${ }^{6}$ This change in trend could possibly be due to the incorporation in 2002 of the chapter on foreign emigration "that takes into account the deregistration of residence informed of by the municipalities, which refer mainly to movements of Spaniards abroad, that have been registered in Consular Office Registers. Similarly, some deregistrations of foreign nationals are recorded when Councils are informed of their return from abroad, although the percentage of that occurrence is unknown" (General Methodology of the EVR, INE). 


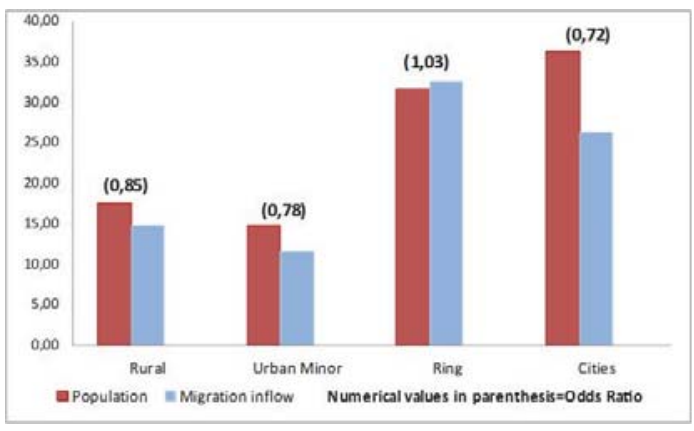

Figure 5. Relative weight of migratory inflow in each habitat. Spain, 2010

Source: Microdata from the Residential Variation Statistics and Municipal Register of 2010 (National Statistic Institute of Spain).

\section{Conclusions}

The changes recorded on growth patterns and population settlements have produced centrifugal expansion models, recently reinforcing the phenomena of suburbanization and urban deconcentration (Hall, 1988: 286-330). The concept of the traditional city and its boundaries cease to be effective if they fail to include these new settlements. Therefore, it is relevant to include and define "Urban Areas", which add peripheries to compact cities. All the territory included in this area has an urban inclination and therefore, we methodologically accept the axiom that all rural areas are always and necessarily outside of that habitat. This conceptual strategy is necessary for the understanding of modern territorial processes. We conclude, therefore, that the three new relevant habitats are: traditional city, suburbs, and rural areas. These areas constitute the pure model, although in practice, it is convenient to add a number of areas scattered throughout the geography which operate as main interior county towns; small and very small cities, which we call Urban Minor, in order to also differentiate them from more rural areas.

Territorial dynamics have undergone several phases, of which it is first worth highlighting the process of population concentration in cities, with the resulting exodus from rural areas. Somewhat later-almost universally-the centrifugal expansion of cities toward their peripheries was recorded, thus giving way to the Urban Areas. Next, traditional cities reached a saturation threshold that caused a standstill of growth (or often a regression) in favour of their peripheries or more rural areas. Presently, different scenarios can be detected: urban revival, consolidation of the rural revival, and balance in growth rates of all habitats. In the latter case, there are three main hypotheses to corroborate the dynamics of the future: reurbanization, counterurbanization, and rebalancing.

Empirically, over the first decade of the 21st century Spain registered its highest population growth rates. This is due to the arrival of immigrants from abroad (especially during the first five years, representing $10 \%$ more inhabitants). Immigrants settled in all the habitats, causing the population rates in all of them to increase. Initially, this allows keeping the previous three hypotheses alive.

The internal migration flow over the studied decade (2001-2010) has exceeded 23 million migrations, gradually increasing from 1.5 million in 2001 and reaching its peak in 2006, with nearly 3 million changes of residence. Since then, values are in the area of 2.5 million. The inflow from abroad explains the majority of population increases in all of the habitats. Over 1.5 million (net balance) settled in cities and in the outskirts (in each). The Urban Minor and the Rural also received over 1.5 million net migrations each during the decade.

In general, considering the habitats in pairs, the larger the habitat, the more unfavourable its flow. This is always true except with regard to the relationship between Urban Minor and Rural, which is favourable for the first. In this sense, the hypotheses put forward which indicate that the trends towards greater dynamism are inversely proportional to the size of the municipality of destination, appear to have some empirical basis. Although cities earn more from the contribution of the external flow, their large deficit with respect to the peripheries makes the latter greater receivers of changes in residence. The only habitat that, overall and only in moderate amounts, gains inhabitants compared to the others, is Urban Minor. This conceals a broader process that has to do with the prevalence of the balance of the peripheries: the peripheralization of the population and the expansion of areas considered to be peripheral. That is to say, part of the urban flow that does not stay in the periphery moves away to other municipalities that are small, but urban, thus enlarging 
the perimeter of the functional area of the cities.

In short, throughout the decade studied, increases were registered that affected all the habitats, although in the rural areas it is necessary to make a distinction that excludes $57 \%$ of it. The rural areas that border with the urban peripheries (Rural Manualized areas) have grown, receiving some of the effects of deconcentration of the urban population. In fact, the greatest increases occurred in the peripheries and these, far from being static categories, partly extend into rural habitats, where the lower social classes tend to settle. In spite of this, given the dynamism shown by all the habitats, the trend towards rebalancing seems to be an increasingly plausible hypothesis.

\section{Acknowledgements}

This article is the result of the work carried out for the project "Analysis and Prognosis of New Residential Migration in Spain", funded by Spain's Ministry of Science and Innovation (CSO2010-16675).

\section{References}

Albrecht, D. E. (2010). Nonmetropolitan Population Trends: Twenty-First Century Updates, Journal of Rural Social Sciences, 25(1), 1-21. Bayona, J., \& Gil-Alonso, F. (2013). Is Foreign Immigration the Solution to Rural Depopulation? The Case of Catalonia (1996-2009), Sociologia Ruralis, 53(1), 26-51.

Beale, C. L. \& Fuguitt, G. (1990). Decade of pessimistic nonmetro population trends ends on optimistic note, Rural Development Perspectives, 6, 14-18.

Bromley R. D. F., Tallon, A. R. \& Roberts, A. J. (2007). New populations in the British city center: evidence of social change from the census and household surveys, Geoforum, 38, 138-154.

Buzar, S., Ogden, P. E., Hall, R., Haase, A., Kabish S. \& Steinführer A. (2007). Splintering urban populations: emergent landscapes of reurbanisation in four European cities, Urban Studies, 44(4), 651-677.

Duque Calvache, R. (2014). La sombra de la gentrificación, Contested Cities, Work Paper No. 14008.

Camarero Rioja, L. A. (1993). Del éxodo rural y del éxodo urbano: ocaso y renacimiento de los asentamientos rurales en España (Madrid: Ministerio de Agricultura Pesca y Alimentación).

Champion A. G. (1992). Urban and regional demographic trends in the developed world, Urban Studies, 29 (3/4), 461-482.

Cheshire, P. (1995). A new phase of urban development in western Europe? The evidence for the 1980s, Urban Studies, 32(7), 10451063.

Cheshire, P., \& Gordon, I. (2006). Resurgent cities? Evidence-based Urban Policy? More Questions than Answers (special issue), Urban Studies, 43(8), 1231-1438.

Collantes, F., Pinilla, V., Sáez, L. A. \& Silvestre J. (2013). Reducing depopulation in rural Spain: The impact of immigration. Population, Space and Place, 1, 31-44. doi: 10.1002/psp.1797.

Couch, C., Karecha, J. Nuissl H.\& Rink D. (2005). Decline and Sprawl: an evolving type of urban development observed in Liverpool and Leipzig, European Planning Studies, 13, 117-136.

Dahms, F. \& McComb, J. (1999). 'Counterurbanization', Interaction and Functional Change in a Rural Amenity Area -A Canadian Example, Journal of Rural Studies, 15(2), 129-146.

De Vries, J. (1995). Problems in the measurement, description, and analysis of Historical Urbanization, in A. v. d. Woude, A. Hayami and J. De Vries (eds); Urbanization in History. A Process of Dynamic Interactions, (pp. 43-60). Oxford: Clarendon Press.

Elliott, J. R. (1997). Cycles within the system: metropolitanisation and internal migration in the US, 1965-90, Urban Studies, 34(1), 21-41.

Farrell, M., Mahon, M., \& McDonagh, J. (2012). The rural as a return migration destination. European Countryside, 4(1), 31-44.

Fielding, A. J. (1986). Migration and Urbanization in Western Europe since 1950, Geographical Journal, 155(1), 60-69.

Frey, W. H. (1995). The new geography of U.S. population shifts: trends toward balkanization, in Reynolds Farley, State of the Union: America in the 1990s, Volume 2, Social Trends (pp. 271-334). New York: Russell Sage.

Fuguitt, G. V. \& Zuiches, J. J. (1975). Residential Preferences and Population Distribution, Demography, 12 (3), 491-504.

García Docampo, M. (2014) Theories of Urban Dynamics. International Journal of Population Research, vol. 2014, Article ID 494871, doi:10.1155/2014/494871

García Docampo, M., \& Otero Enríquez, R. (2012). Transición territorial: modelo teórico y contraste con el caso español. Revista Española de Investigaciones Sociológicas, 139 (1), 133-162.

García Sanz, B. (1997). Últimas tendencias de la población rural según el Padrón municipal de habitantes de 1996. Agricultura y sociedad, (84), 279-296.

Goldstein, J. R., Sobotka, T. \& Jasilioniene, A. (2009). The End of "Lowest-Low" Fertility? Population and development review, 35(4), 663-699.

Gordon, P. (1979). Deconcentration without a 'clean break', Environment and Planning A, 11, 281-290.

Gurrutxaga, M. (2013). Changes in rural-urban sex ratio differences in the young professional age group as an indicator of social sustainability in rural areas: a case study of continental Spain, 2000-2010. Area, 45(3), 337-347.

Haase, A., Kabisch, S., Steinführer, A., Bouzarovski, S., Hall, S. R. \& Ogden, P. (2010). Emergent Spaces of Reurbanisation: Exploring the Demographic Dimension of inner-city Residential Change in a European Sitting, Population, Space and Place, 16, 443-463. 
Halfacree, K. (2012). Heterolocal Identities? Counter-Urbanisation, Second Homes, and Rural Consumption in the Era of Mobilities, Population, Space and Place, 18, 209-224.

Hall, P. (1988). Cities of Tomorrow. An intellectual history of urban planning and design in the twentieth century. (Oxford: Basil Blackwell).

Hall, P. \& D. Hay (1980). Growth Centers in the European Urban System. (Berkeley: University of California Press).

Hierro, M. (2009). Un estudio comparado de la dispersión migratoria en España a nivel regional, provincial, por tipos de municipios y grupos de edad (1986-2003). AGER. Revista de Estudios sobre Despoblación y Desarrollo Rural, 5, 7-34.

Janoschka, M., Sequera J. \& Salinas, L. (2014). Gentrification in Spain and Latin America—A Critical Dialogue. International Journal of Urban and Regional Research, 38(4), 1234-1265

Johnson, K. M. (2006.). Demographic Trends in Rural and Small Town America. Reports on Rural America, 1(1). (Durham: University of New Hampshire, Carsey Institute).

Johnson, K. M., Nucci, A. \& Long, L. (2005). Population Trends in Metropolitan and Nonmetropolitan America: Selective Deconcentration and Rural Rebound, Population Research and Policy Review, 24, 527-542.

Kasanko, M., Barredo, J. I., Lavalle, C., McCormick, N., Demicheli, L., Sagris, V., \& Brezger, A. (2006). Are European Cities Becoming Dispersed? A Comparative Analysis of Fifteen European Urban Areas. Landscape and Urban Planning, 77, 111-130.

Lamela Viera, C. (2006). Migración interna de los extranjeros. 238-282, in A. Izquierdo et al., Demografía de los extranjeros: incidencia en el crecimiento de la población. Madrid: Fundación BBVA.

Long, L. \& Nucci, A. (1997). The 'Clean Break' Revisited: is US Population Again Deconcentrating?, Environment and Planning A, 29, 1355-1366.

Ministerio de la Vivienda. (2007). Atlas estadístico de las áreas urbanas de España. Madrid: Centro de Publicaciones del Ministerio de la Vivienda. Gobierno de España.

Morillo, M. J. \& Susino, J. (2010). La emigración con origen en las áreas metropolitanas andaluzas: El perfil de sus protagonistas. 181196, in I. Pujadas et al. (Eds.), Población y Espacios urbanos. Barcelona: Departamento de Geografía Humana de la UB.

Nel.lo, O. (2004). ¿Cambio de siglo, cambio de ciclo? Las grandes ciudades españolas en el umbral del s. XXI. Ciudad y Territorio: Estudios Territoriales, 36(141-142), 523-542.

Ogden, P. E. \& Hall, R. (2000) Households, Reurbanisation and the Rise of Living Alone in the Principal French Cities, 1975-1990, Urban Studies, 37, 367-390.

Oliva, J. (2010). Rural Melting-pots, Mobilities and Fragilities: Reflections on the Spain Case, Sociologia ruralis, 50 (3), $278-295$.

Pallarès-Blanch, M., Prados Velasco, M. J., \& Tulla Pujol, A. F. (2014). Naturbanization and Urban-Rural Dynamics in Spain: Case Study of New Rural Landscapes in Andalusia and Catalonia, European Countryside, 6(2), 118-160.

Parr, J. B. (2012). The Spatial-Cycle Model (SCM) Revisited, Regional Studies, 46(2), 217-228.

Pozo Rivera, E. \& García Palomares, J. C. (2009). Inmigración y cambio demográfico en la región metropolitana madrileña entre 1996 y 2006, Anales de geografía, 29(1), 111-138.

Priemus, H. (2003). Changing Urban Housing Markets in Advanced Economies, Housing, Theory and Society, 21, 2-16.

Reher, D. S. \& Silvestre, J. (2009). Internal Migration Patterns of Foreign-Born Immigrants in a Country of Recent Mass Immigration: Evidence from New Micro Data for Spain, International Migration Review, 43 (4), 815-849.

Rivera, M. J. (2013). Translating Ex-Urban Dwellers' Rural Representations into Residential Practices and Rural Futures. 25-39 in L Silva and E. Figueirido (eds), Shaping Rural Areas in Europe (Dordrecht: Springer).

Rodríguez, V., Fernández-Mayoralas, G., \& Rojo, F. (2004). International Retirement Migration: Retired Europeans Living on the Costa del Sol, Spain. Population Review, 43(1), 1-36.

Silvestre, J. (2002). Las emigraciones interiores en España durante los siglos XIX y XX: una revisión bibliográfica. Ager. Revista de Estudios sobre despoblación y desarrollo rural, 2, 227-248.

Solana-Solana, M. (2010). Rural Gentrification in Catalonia, Spain: A Case Study of Migration, Social Change and Conflicts in the Empordanet Area. Geoforum, 41(3), 508-517.

Turok, I. \& Mykhnenko, V. (2007). The Trajectories of European Cities, 1960-2005, Cities, 24(3), 165-182.

Van den Berg, L., Drewett, L., Klaassen, L. H., Rossi, A. and Vijverberg, C. H. T. (1982). Urban Europe: A Study of Growth and Decline (Oxford: Pergamon Press).

Vining, D. R. \& Strauss, A. (1977). A Demonstration of the Current Deconcentration of Population in the United States is a Clean Break with the Past, Environment and Planning, 9, 751-758.

Wang, X. (2006). Rethinking the Nonmetropolitan Turnaround: Renewed Rural Growth or Expanded Urbanization? (Dissertation of doctoral these, Texas A\&M University).

Wardwell, J. M. (1977). Equilibrium and Change in Nonmetropolitan Growth, Rural Sociology, 42, 156-179. 